\title{
Localization of sterodogenic acute regulartory (StAR) protein in testis of Thai red jungle fowl (Gallus gallus gallus)
}

\author{
IAMSAARD, S. ${ }^{1,2 *}$, CHAICHUN, A. ${ }^{1}$ and SUKHORUM, W. ${ }^{1}$
}

\author{
${ }^{1}$ Department of Anatomy, Faculty of Medicine, Khon Kaen University, Khon Kaen 40002, Thailand \\ ${ }^{2}$ Center for Research and Development of Herbal Health Products, Faculty of Pharmaceutical Sciences, Khon Kaen \\ University, Khon Kaen 40002, Thailand \\ *E-mail: sittia@kku.ac.th
}

\begin{abstract}
Introduction: Thai red jungle fowl (Gallus gallus gallus) has been focusing on genetic profiles besides phenotypical features. The husbandry of this species is still limited. Basic understanding of its reproductive systems may be useful for breeding applications. Additionally, the morphology of testes and epididymis of Thai red jungle fowl has never been elucidated. Materials and Methods: This study has examined the gross structure and histology of those organs of male Thai Gallus gallus gallus at $24^{\text {th }}$ weeks (age and sexual maturity). Moreover, the localization of sterodogenic acute regulartory (StAR) protein in the testis was also performed by immunohistochemistry. Results: The results showed that the mature testes were oval shape with $1.56 \pm 0.584 \mathrm{~cm}$. in length and $1.20 \pm 0.067 \mathrm{~cm}$. in width, respectively. General histology of testes and epididymis was similar to those of maturely domestical birds. Expectedly, the StAR protein was localized in the leydig cells of Thai red jungle fowl. Conclusion: This study has not only demonstrated the morphology of testis and epididymis but also shown the presence of testicular StAR protein of Thai red jungle fowl for the first time. These findings are fundamental data that may be applied to the breeding process.
\end{abstract}

Keywords: Gallus gallus gallus, testis, epididymis, sterodogenic acute regulartory (StAR) protein.

\section{Introduction}

In Thailand, there are various species of chicken (MEKCHAY, SUPAKANKUL, ASSAWAMAKIN et al., 2014). They are raised in commercial, home or backyard farms supporting people as they are an excellent nutritional source. The purpose of husbandry in some domestic species is for sport entertainment like the fighting cocks or for pleasure of looking at them like bantam cocks. Interestingly, it has long been traditionally believed that parts of Thai red jungle fowl (Gallus gallus gallus), genetically proved as the matriarchic ancestor of all domestic breeds (FUMIHITO, MIYAKE, SUMI et al., 1994) are elixirs. For such reason, the jungle hunters in rural area of Thailand are trying to chase them for sale or consumption. By talking to the local hunters, male jungle fowl is very sensitive to human handles mostly resulting in dead after chasing from the jungle. Therefore, it is a challenging to breed them to be a domestic species. Unfortunately, only few home farms in rural areas in Khon Kaen province are successful to manage this Thai red jungle fowl as their environments are closed to jungle or because of their expertise. Basic researches on reproductive system of this cock species are very important for understanding of the fundamental functions in breeding applications.

The reproductive system of avians including domestic chickens in terms of general gross morphology and histology has been well documented (PARKER, MCKENZIE and KEMPSTER, 1942; BENNETT, 1947; LAKE, 1957; LEROY, BARBIER and AUZANNEAU, 1968; BUDRAS and SAUER, 1975a, b; KUGLER, 1975; MERCADANTE, ORSI, VICENTINI et al., 1983; BULL, MARTINS, CESÁRIO et al., 2007). In addition, the molecules involved in the steriodogenesis like sterodogenic acute regulartory (StAR) protein in chicken were also determined (SECHMAN, PAWLOWSKA and HRABIA, 2011; SECHMAN, ANTOS, KATARZYŃSKA et al., 2014). However, the expressions of StAR mRNAs and proteins have been investigated in only ovarian laying hens (SECHMAN, PAWLOWSKA and HRABIA, 2011; SECHMAN, ANTOS, KATARZYŃSKA et al., 2014) and other gonadal vertebrates (BURRONE, RAUCCI and DI FIORE, 2012; NANJAPPA, SIMON and AKINGBEMI, 2012; WARITA, MITSUHASHI, FUKUI et al., 2013). In this study, we therefore attempted to investigate the morphology of male reproductive organs together with localization of StAR protein in the testis of Thai red jungle fowl (Gallus gallus gallus) that they have never been previously reported.

\section{Materials and Methods}

Three males of Thai Gallus gallus gallus at $24^{\text {th }}$ weeks (age and sexual maturity (described in BULL, MARTINS, CESÁRIO et al., 2007) were provided by a rural farm from Amphore Nampong, Khon Kaen province, Thailand. These animals (Fl generation) were bred from the same wild parent that they were caught from same jungle and further fed them for three months.

The animals were sacrificed by cervical dislocation before abdominal laparotomy. After removal of visceral gastrointestinal organs, the testes and epididymis were carefully removed to study of general morphology and histology. The gross morphology of samples was photographed by a digital Nikon camera. Immediately after sacrifice, these organs were 
cleaned of fats and fixed in $10 \%(\mathrm{v} / \mathrm{v})$ formalin in phosphate buffered saline (PBS) ( $\mathrm{pH} 7.4$ ), dehydrated, embedded in paraffin, sectioned at 5-7 $\mu \mathrm{m}$ thickness, and stained with hematoxylin-eosin (described in IAMSAARD, SUKHORUM, SAMRID et al., 2014).

For immunohistochemistry (IHC), the testicular section was blocking nonspecific protein binding with 5\% BSA in PBST (phosphate buffer saline ( $\mathrm{pH} 8.4$ ) containing $0.1 \%$ Tween-20) for $\mathrm{l} \mathrm{h}$ at room temperature. After blocking, the section were incubated with polyclonal StAR antibody [(FL-285: sc-25806: Santa Cruz Biotechnology Inc., USA) at a dilution of 1:1000] in $2.5 \%$ BSA in PBST overnight at $4{ }^{\circ} \mathrm{C}$, washed (PBST, three times, $5 \mathrm{~min}$ for each time) and incubated with horseradish peroxidase-conjugated goat anti-rabbit/anti-mouse secondary antibodies (Millipore Co., USA) respectively. The StAR proteins on testicular sections were detected using NovaRED ${ }^{\mathrm{TM}}$ Peroxidase Substrate (Burlingame, CA USA). All H\&E and IHC sections were examined under a Nikon light ECLIPSE E200 microscope equipped with a DXM1200 digital camera.

\section{Results}

In gross aspect (Figure 1), the testes at sexually mature state $\left(24^{\text {th }}\right.$ weeks $)$ of Thai Gallus gallus gallus were oval shape with smooth surface. There were $2.156 \pm 0.584 \mathrm{~cm}$. in length and were approximately $1.20 \pm 0.067 \mathrm{~cm}$ in width (Figure 1). At the superolateral side to the testes, they were existed by epididymis and ductus deferens (Figure 1).

In histological aspects, whole testis was covered by albunigeous tunic and divided into small lobules by septum projecting of its albunigeous tunic. Figure 2 showed the fine packing of seminiferous tubules with their peritubular (interstitial tissues) tissues. Within seminiferous tubule, all epithelial germ cells and Sertoli's cells can be observed (Figure 2). It was clear that interstitial tissues consisted of Leydig's cells, fibroblasts, very

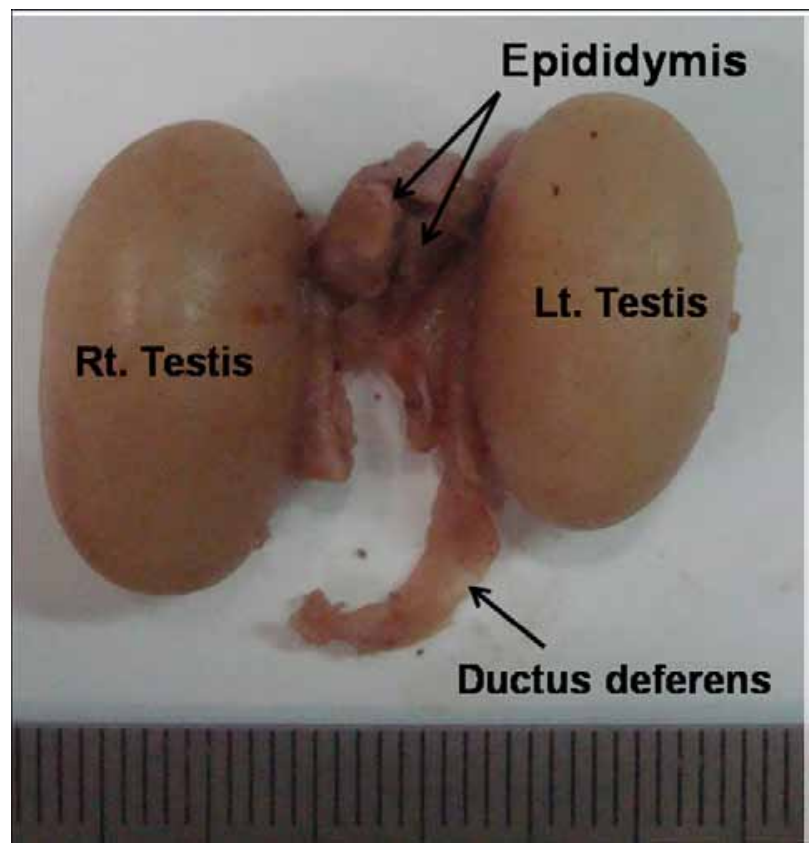

Figure 1. Photograph showing the representative gross morphology of right and left mature testes, epididymes, and a ductus deferens of Thai Gallus gallus gallus. thick connective tissues, lymphatics, and prominent blood vessels (Figure 2).

Moreover, the expressions of sterodogenic acute regulartory (StAR) proteins were observed in the cytoplasmic Leydig's cells of Thai Gallus gallus gallus as compared to the negative control by immunohistochemistry (Figure 3). No positive results were investigated in seminiferous epithelial cells (Figure 3) and ductus epididymis (data not shown).

For histological study of epididymis (Figure 4), each ductus epididymis wall was surrounded by thin smooth muscle cells and thick connective tissues with blood vessels were located between the ductus. This duct has various diameters of lumen containing mature sperm mass and lined with pseudo stratified columnar epithelium with stereocilia (Figure 4).

\section{Discussion}

In general, testicular shape of domestic birds or fowls at sexual maturity period ( 24 weeks or 167 days based on BULL, MARTINS, CESÁRIO et al., 2007) is oval structure (ARTONI, 1993; AMER and SHAHIN, 1975; BULL, MARTINS, CESÁRIO et al., 2007). Obviously, the shape of mature testes (Figure 1) in Thai red jungle fowl (Gallus gallus gallus) corroborate with those investigations.

In comparative analysis of the right and left testis length in domestical fowl (Gallus domesticus) investigated by Bull, Martins, Cesário et al. (2007), their results demonstrated that the left testis had higher length at 24 weeks. In contrast to our observations, both length and the width of right and left testes are not significantly different (Figure 1). We assumed

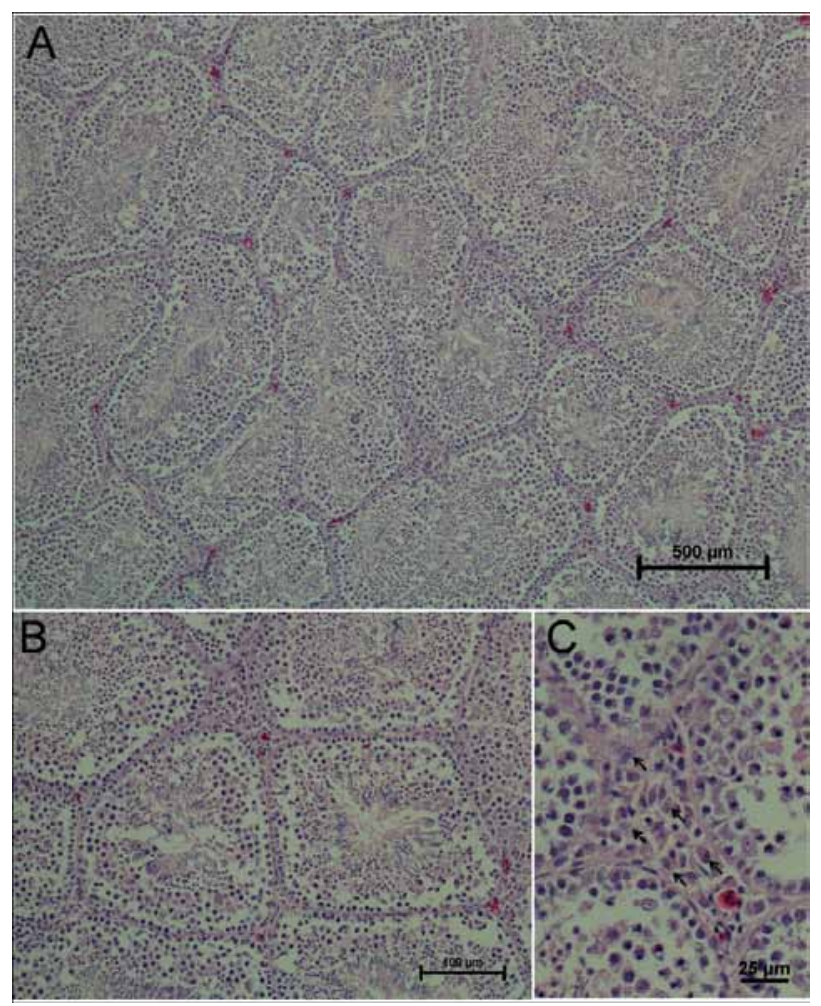

Figure 2. Photographs showing representative histology (H\&E) of testis of Thai Gallus gallus gallus at low and medium magnifications $(\mathrm{A}, \mathrm{B})$ and at high magnification showing interstitial tissues $(\mathrm{C})$; arrows $=$ Leydig's cells. 


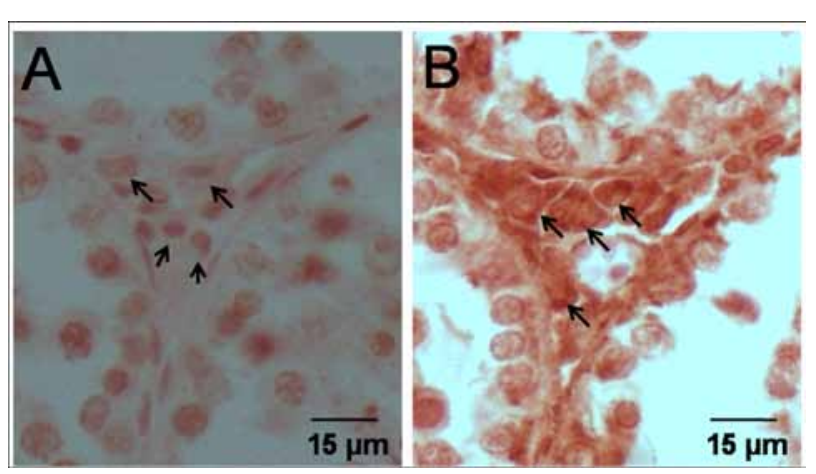

Figure 3. Immunolocalization of sterodogenic acute regulartory (StAR) protein in interstitial tissues of Thai Gallus gallus gallus. Arrows = Leydig's cells. (A) negative control; (B) positive Leydig's cells.
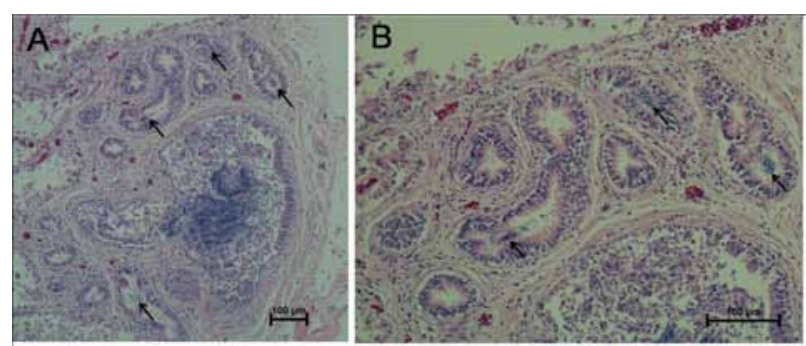

Figure 4. Photographs showing representative histology (H\&E) of epididymis of Thai Gallus gallus gallus at low and medium magnifications (A, B), respectively. Arrows = sperm mass.

that testes weights observed in present study were also not different due to the morphometric results of both sides of testes are not different. There was an excellent work reported by Bull, Martins, Cesário et al. (2007) and they demonstrated that testicular weight variation rate was due to the increasing of the animal ages (ranged from 24, 23, 48, 59, and 67 weeks, respectively). They concluded that the maximum weight of the right and left testis of 50 male domestical fowls occurred with 167 and 210 days (BULL, MARTINS, CESÁRIO et al., 2007). We unfortunately could not perform such experiments to compare those variation rates because of limitation in animal numbers. Once the breeding or husbandry system of Thai red jungle fowl in Khon Kaen province is consistent to produce more real blood Thai fowls, our groups will observe those variation immediately.

Similarly to the works done by Gray (1937), Mercadante, Orsi, Vicentini et al. (1983), Artoni (1993) and Bull, Martins, Cesário et al. (2007), we have also observed that testes of Thai red jungle fowl were retroperitoneal organs and parallel located at the side of the body median line with the present of the testicular hilum.

In histological results, the testicular and epididymal architectures observed in Thai red jungle fowl (Gallus gallus gallus) were similar to those histologies observed in domestic fowl (Gallus domesticus), which reported by Tingari and Lake (1972). These investigations imply that both species have common development of male reproductive system.

The expression and localization of sterodogenic acute regulartory (StAR) protein was documented in non-avian gonadal vertebrates (BURRONE, RAUCCI and DI FIORE, 2012; NANJAPPA, SIMON and AKINGBEMI, 2012; WARITA, MITSUHASHI, FUKUI et al., 2013), human endocrine cell lines (MIKHAYLOVA, JÄÄSKELÄINEN, JÄÄSKELÄINEN et al., 2008; TKACHENKO, JÄÄSKELÄINEN, JÄÄSKELÄINEN et al., 2011), and only ovarian laying hens (SECHMAN, PAWLOWSKA and HRABIA, 2011; SECHMAN, ANTOS, KATARZYŃSKA et al., 2014). For that first time, this study has already showed that StAR protein is also expressed in the leydig cells of Thai red jungle fowl (Gallus gallus gallus). This may imply that the steroidal hormones of mature red jungle fowl is also produced by leydig cells via the initial machinery of StAR protein.

\section{References}

AMER, FI. and SHAHIN, MA. The post-hatching development of the gonads in the fowl, Gallus domesticus. Annales Zoologici, 1975, vol. 11, n. 1, p. 1-25.

ARTONI, SMB. Considerações sobre a morfologia e a histofisiologia do testiculo da codorna (Coturnix cournix japonica). Botucatu: Instituto de Biociências, Universidade Estadual Paulista, 1993. [Thesis].

BENNETT, CH. Relation between size and age of the gonads in the fowl from hatching date to sexual maturity. Poultry Science, 1947, vol. 26, n. 2, p. 99-104. http://dx.doi.org/10.3382/ps.0260099.

BUDRAS, KD. and SAUER, T. Morphology of the epididymis of the cock (Gallus domesticus) and its effect upon the steroid sex hormone synthesis. I. Ontogenesis, morphology and distribution of the epididymis. Anatomy and Embryology, 1975a, vol. 148, n. 2, p. 175-196. http://dx.doi.org/10.1007/BF00315268. PMid:1211661.

BUDRAS, KD. and SAUER, T. Morphology of the epididymis of the cock (Gallus domesticus) and its effect upon the steroid sex hormone synthesis. II. Steroid sex hormone synthesis in the tubuli epididymidis and the transformation of the ductuli aberrantes into hormone producing noduli epididymidis in the capsule of the adrenal gland of the capon. Anatomy and Embryology, 1975b, vol. 148, n. 2, p. 197 213. http://dx.doi.org/10.1007/BF00315269. PMid:1211662.

BULL, ML., MARTINS, MRFB., CESÁRIO, MD., PADOVANI, CR. and MENDES, AA. Anatomical study on domestical fowl ( Gallus domesticus) reproductive system. International Journal of Morphology, 2007, vol. 25, n. 4, p. 709-716. http://dx.doi.org/10.4067/S071795022007000400007.

BURRONE, L., RAUCCI, F. and DI FIORE, MM. Steroidogenic gene expression following d-aspartate treatment in frog testis. General and Comparative Endocrinology, 2012, vol. 175, n. 1, p. 109-117. http://dx.doi.org/10.1016/j.ygcen.2011.10.006. PMid:22036840.

FUMIHITO, A., MIYAKE, T., SUMI, S., TAKADA, M., OHNO, S. and KONDO, N. One subspecies of the red junglefowl (Gallus gallus gallus) suffices as the matriarchic ancestor of all domestic breeds. Proceedings of the National Academy of Sciences of the United States of America, 1994, vol. 91, n. 26, p. 12505-12509. http://dx.doi. org/10.1073/pnas.91.26.12505. PMid:7809067.

GRAY, JC. The anatomy of the male genital ducts in the fow. Journal of Morphology, 1937, vol. 60, n. 2, p. 393-405. http://dx.doi. org/10.1002/jmor.1050600206.

IAMSAARD, S., SUKHORUM, W., SAMRID, R., YIMDEE, J., KANLA, P., CHAISIWAMONGKOL, K., HIPKAEO, W., FONGMOON, D. and $\mathrm{KONDO}, \mathrm{H}$. The sensitivity of male rat reproductive organs to monosodium glutamate. Acta Medica Academica, 2014, vol. 43, n. 1, p. 3-9. http://dx.doi.org/10.5644/ama2006-124.94. PMid:24893633.

KUGLER, P. Histological and histochemical studies on testis, epididymis and ductus defrens of the rooster (Gallus domesticus). 
Gegenbaurs Morphologisches Jabrbuch, 1975, vol. 121, n. 3, p. 257288. PMid:172401.

LAKE, PE. The male reproductive tract of the fowl. Journal of Anatomy, 1957, vol. 91, n. 1, p. 116-129. PMid:13405819.

LEROY, P., BARBIER, Y. and AUZANNEAU, C. The male Gallus domesticus $\mathrm{X}$ female numida meleagris hybrid. Histology of the testicle: comparison with thedomestic cock and the guinea-cock. Archives d'Anatomie, d'Histologie et d'Embryologie Normales et Expérimentales, 1968, vol. 51, n. 1, p. 399-406. PMid:4905280.

MEKCHAY, S., SUPAKANKUL, P., ASSAWAMAKIN, A., WILANTHO, A., CHAREANCHIM, W. and TONGSIMA, S. Population structure of four Thai indigenous chicken breeds. BMC Genetics, 2014, vol. 15, n. 1, p. 40. http://dx.doi.org/10.1186/1471-2156-15-40. PMid:24674423.

MERCADANTE, MCS., ORSI, AM., VICENTINI, CA., VALENTE, MM. and DIAS, SM. Observações anatômicas sobre o trato reprodutor masculino do Pombo (Columba livia, L.). Revista de Ciências Biomédicas, 1983, vol. 4, p. 37-44.

MIKHAYLOVA, IV., JAASKELAINEN, T., JAASKELAINEN, J., PALVIMO, JJ. and VOUTILAINEN, R. Leukemia inhibitory factor as a regulator of steroidogenesis in human NCI-H295R adrenocortical cells. The Journal of Endocrinology, 2008, vol. 199, n. 3, p. 435-444. http://dx.doi.org/10.1677/JOE-08-0377. PMid:18796549.

NANJAPPA, MK., SIMON, L. and AKINGBEMI, BT. The industrial chemical bisphenol A (BPA) interferes with proliferative activity and development of steroidogenic capacity in rat Leydig cells. Biology of Reproduction, 2012, vol. 86, n. 5, p. 135. http://dx.doi.org/10.1095/ biolreprod.111.095349. PMid:22302688.

PARKER, JE., MCKENZIE, FF. and KEMPSTER, HL. Development of the testes and combs of White Leghorn and New Hampshire organs. Poultry Science, 1942, vol. 21, n. 1, p. 35-44. http://dx.doi. org/10.3382/ps.0210035
SECHMAN, A., ANTOS, P., KATARZYŃSKA, D., GRZEGORZEWSKA, A., WOJTYSIAK, D. and HRABIA, A. Effects of 2,3,7,8-tetrachlorodibenzop-dioxin on secretion of steroids and STAR, HSD3B and CYP19AI mRNA expression in chicken ovarian follicles. Toxicology Letters, 2014, vol. 225, n. 2, p. 264-274. http://dx.doi.org/10.1016/j. toxlet.2013.12.021. PMid:24398026.

SECHMAN, A., PAWLOWSKA, K. and HRABIA, A. Effect of 3,3',5-triiodothyronine and 3,5-diiodothyronine on progesterone production, cAMP synthesis, and mRNA expression of STAR, CYPIIAl, and HSD3B genes in granulosa layer of chicken preovulatory follicles. Domestic Animal Endocrinology, 2011, vol. 41, n. 3, p. 137-149. http:// dx.doi.org/10.1016/j.domaniend.2011.05.007. PMid:21798688.

TINGARI, MD. and LAKE, PE. Ultraestrutural evidence for resorption of spermatozoa and testicular fluid in the excurrent ducts of the testis of the domestic fowl (Gallus domesticus). The Journal of the Society for Reproduction and Fertility, 1972, vol. 31, n. 3, p. 373-381. http:// dx.doi.org/10.1530/jrf.0.0310373. PMid:4648123.

TKACHENKO, IV., JÄÄSKELÄINEN, T., JÄÄSKELÄINEN, J., PALVIMO, JJ. and VOUTILAINEN, R. Interleukins $l \alpha$ and $1 \beta$ as regulators of steroidogenesis in human NCI-H295R adrenocortical cells. Steroids, 2011, vol. 76, n. 10-11, p. 1103-1115. http://dx.doi. org/10.1016/j.steroids.2011.04.018. PMid:21600230.

WARITA, K., MITSUHASHI, T., FUKUI, S., OHTA, K., SUZUKI, S., MIKI, T., TAKEUCHI, Y., YOKOYAMA, T., KITAGAWA, H., SUGAWARA, T. and HOSHI, N. Immunohistochemical analysis of steroidogenic acute regulatory protein (StAR) and StAR-binding protein (SBP) expressions in the testes of mice during fetal development. Reproductive Biology, 2013, vol. 13, n. 1, p. 92-95. http://dx.doi. org/10.1016/j.repbio.2013.01.172. PMid:23522077.

Received December 14, 2014 Accepted February 25, 2016 